\title{
Analisis Stakeholders pada Pelatihan Manajemen Strategis dengan Metode Daring di Badan Pengembangan Sumber Daya Manusia Provinsi DKI Jakarta
}

\author{
Yurianto \\ BPSDM Provinsi DKI Jakarta
}

\section{ARTICLE INFO \\ Article History:}

Received 11 September 2021

Revised 19 Desember 2021

Accepted 23 Desember 2021

Published 30 Desember 2021

\section{Keywords:}

Managemen Strategis;

Pelatihan;

On Line;

PNS;

Pemangku Kepentingan

\begin{abstract}
The level of quality of an online learning system is highly dependent on various factors. The main objective of this study is to analyze the role of each stakeholder in strategic management training. The location of research activities is carried out at BPSDM DKI Jakarta Province. In collecting data, used purposive sampling technique. Based on the results of stakeholder identification, it is known that there are 15 (fifteen) stakeholders involved in strategic management training. Based on the analysis, it was found that training) is needed by Civil Servants (PNS) to improve competence. The stakeholders who are the key to implementing strategic management training include BPSDM, BKD, BPKD, BAPPEDA. In order training be optimal, it has to be collaborated among stakeholders professionally dan proportionally. Furthermore, collaboration is effective and efficient if it is supported by balanced and respectful communication, coordination, and cooperation.
\end{abstract}

\begin{abstract}
Tingkat kualitas suatu pembelajaran dengan system daring sangat tergantung dari berbagai factor. Tujuan utama kajian ini adalah menganalisis peran masing masing stakeholder dalam pelatihan manajemen strategis. Lokasi kegiatan penelitian dilakukan di BPSDM Provinsi DKI Jakarta. Dalam pengumpulan data, digunakan teknik purposive sampling. Berdasarkan hasil identifikasi pemangku kepentingan diketahui bahwa terdapat 15 (lima belas) pemangku kepentingan yang terlibat dalam pelatihan manajemen strategis. Berdasarkan analisis ditemukan bahwa pelatihan) sangat dibutuhkan oleh Pegawai Negeri Sipil (PNS untuk meningkatkan kompetensi. Yang termasuk pemangku kepentingan dan menjadi kunci pelaksanaan pelatihan manajemen strategis antara lain adalah BPSDM, BKD, BPKD, BAPPEDA. Agar pelatihan optimal harus ada kolaborasi antar pemangku kepentingan secara profesional dan proporsional. Selanjutnya kolaborasi yang efektif dan efeisien jika didukung komunikasi, koordinasi dan kerjasama yang seimbang dan saling menghormati.
\end{abstract}

Corresponding Author:
Yurianto,
Email: yurimerdeka@gmail.com
How to Cite: Yurianto. (2021). Analisis stakeholders pada pelatihan manajemen strategis dengan metode daring di badan
pengembangan sumber daya manusia Provinsi DKI Jakarta. Sosio e-Kons, 13(03), 230-242

\section{PENDAHULUAN}

Tingkat kualitas suatu pembelajaran dengan sistem daring sangat tergantung dari berbagai faktor. Faktor - faktor tersebut perlu diidentifikasi secara terinci dan detil agar mudah dalam pengelolaannya. Dengan pengelolaan factor tersebut secara terstruktur dan profesional maka kualitas hasil pembelajaran akan lebih tepat sasaran dan manfaatnya akan lebih optimal.

Menurut Tim komunikasi Publik Gugus Tugas Nasional (https://covid19.go.id) terdapat tujuh kiat untuk sukses dalam pembelajaran model daring ini. Yang pertama adalah bahwa pengajar dan peserta serta penyelenggaraan harus bergembira dan enjoy. Yang kedua adalah kelas dibagi menjadi kelompok belajar yang kecil hal ini dimaksudkan untuk memudahkan dalam melakukan diskusi dan kerja kelompok. Dengan diskusi dan kerja kelompok membuat waktu belajar akan lebih efektif. Alasan 
yang ketiga adalah bahwa pengajar dan peserta pembelajaran agar dapat mengerjakan tugas kelompok dan menciptakan suatu tantangan atau lomba yang memerlukan kolaborasi antar kedua komponen tersebut.

Keempat perlu alokasi waktu yang cukup bagi yang tertinggal dalam kelas daring. Hal ini dimaksudkan agar yang tertinggal mempunyai waktu yang cukup untuk memahami sesi pemberlajaran. Pastikan bahwa semua peserta sudah mempunyai kesamaan dalam pemahamam terhadap subyek yang dijarakan. Kelima peserata dan pengajar harus foikus dan penguatan pada subyek pemateri pelatihan yang dapat membantu kemampuan peserta. Keenam metode ATM amati tiru dan modifikasi perlu diterapkan agar cara guru lain belajar yang lebih bagus itu menjadi contoh yang baik. Ketujuh bekerja sama dan terus berkreasi sangat dibutuhkan. Hal ini merupakan cara untuk menghindari kejenuham baik pengajar maupaun peserta.

Untuk mencapai hal tersebut diperlukan kerja sama para pemangku kepentingan. Kerja sama yang konstruktif, sistematik, koordinatif, dengan semangat kolaborasi antar pemangku kepentingan maka akan menentukan kualitas hasil pembelajaran system daring. Dengan demikian maka jelas bahwa kerja sama yang berkesinambungan sangat sentral dalam menentukan hasil pembelajaran daring tersebut.

Kondisi di atas juga sejalan dengan apa yang terjadi pada pembelajaran manajemen strategik di BPSDM Provnisi DKI Jakarta. Pembelajaran ini dilakukan secara daring, dan pemangku kepentingan jumlahnya relative banyak dan peran serta fungsinya bervariasi. Untuk itu, guna mencapai hasil pembelajaran manajemen strategik yang berkualitas, semua pemangku kepentingan harus terus melakukan komunikasi dan koordinasi secara kemitraan.

Terlebih lagi, mata pelatihan manajamen strategik sangat menunjang dan penting dalam implementasi pelaksanaan perencanaan pembangunan daerah di organisasi perangkat daerah. Hal ini disebabakan karena dokumen perencanaan pembangunan daerah disusun dengan pendekatan manajemen strategik Penyusunan rencana kerja pemerintah daerah, penyusunan rencana pembangunan jangka menenngah daerah, penyusunan rencana strategis serta pengendalian pembangunan daerah memerlukan pemahaman yang komprehensif tentang manajemen strategik.

Selain itu, fungsi manajemen strategik juga sangat penting dalam menyusun perencanaan pembangunan daerah. Wright, Kroll, dan Parnell dalam Ray (2018) bahwa manajemen strategis merupakan suatu proses yang berkelanjutan dan merupakan penentu misi dan tujuan organisasi dalam konteks lingkungan eksternal dan internal, kekuatan dan kelemahan, merumuskan strategi yang tepat, menerapkan strategi-strategi, dan dengan menggunaka kontrol guna memastikan strategi organisasi berhasil dalam mencapai tujuannya. Jadi jelas bahwa manajemen suatu proses yang terus menerus untuk mencapai tujuan yang telah ditetapkan. Dengan demikian , manajemen strategis sangat penting dalam pencapaian tujua suatu organisasi.

Dengan pentingnya peran manajemen strategik maka peningkatan pemahaman materi ini kepada para ASN diperlukan baik yang ada di Satuan Kerja Perangkat Daerah (SKPD) maupun di Unit Kerja Perangkat Daerah (UKPD). Sebgaimana diamanatkan Undang-Undang No 23 tahun 2014 tentang Pemerintahan Daerah bahwa Perangkat Daerah menyusun rencana strategis. Dalam menyusun rencana strategis tersetbu diperlukan pengetahuan tentang manajemen strategik. Untuk itulah pembelajaran manajemen strategik menjadi suatu keharusan agar landasan teori perencanaan pembangunan daerah dapat dikuasai oleh para perencana pembangunan terutama para Aparat Sipil Negara (ASN) di lingkungan Pemerintahan Daerah. Hal ini mengingat bahwa pegawai ASN berfungsi sebagai pelaksana kebijakan public, pelayan publik; dan perekat dan pemersatu bangsa (Undang Undang No 5 tahun 2014 tentang Aparatur Sipil Negara. Dengan demikian maka pembelajaran manajemen strategik menjadi sangat penting.

Agar pembelajaran manajemen strategik berjala dengan efektif dan efisien maka diperlukan proses dan mteode pembelajaran yang tepat. Selanjutnya agar hal ini terwujud maka unsur yang penting adalah melakukan analisis pemangku kepentingnan yang mendalam pada proses pembelajaran manajemen strategik. 
Disadari bahwa untuk meningkatkan pengetahuan, keterampilan dan kemampuan sumber daya manusia aparatur dalam menghadapi segala perubahan kebijakan regulasi, perlu disusun program Pelatihan Manajemen Strategik bagi Pegawai Pemerintah Provinsi Daerah Khusus Ibukota Jakarta. Sejalan dengan hal tersebut pertanyaan yang mendasar adalah siapa saja yang terlibat dalam proses pelatihan pembelajaran manajeman strategik agar pembangunan berjalan dengan baik. Dengan demikian maka tujuan kajian ini adalah:

1. Mengidenrtifikasi pemanngku kepentingan dalam proses pelatihan manajemen strategis

2. Menganalisis peran masing masing stakeholder dalam pelatihan manajemen strategis

3. Memetakan peran masaing masing pemanagku kepentingan dalam proses pembelajaran manajemen strategis

4. Mengklasifikasikan para stakeholders dalam pelaksanaan pelatihan Manajemen Strategis

5. Menggambarkan hubungan antar stakeholders yang terlibat dalam pengembangan Pelatihan Manajemen Strategis

\section{METODE}

Dalam pencapaian tujuan yang telah ditetapkan oleh organisasi, pemangku kepentingan merupakan factor yang sangat penting dan central. Secara konsep pemangku kepentingan dapat diidentifikasi sebagai individu atau kelompok yang memiliki kepentingan dan dapat memberikan pengaruh kepada suatu objek (Hidayah et al., 2019). Selanjutnya dalam praktiknya bahwa setiap pemangku kepentingan memiliki kepentingan dan pengaruh dalam pencapaian suatu tujuan yang berbeda-beda (Bryson, 2004), dengan demikian maka mengakibatkan bahwa tanggung jawab yang dimiliki juga berbeda-beda. Dalam hal ini, Bryson, 2004 juga mengatakan bahwa secara fungsi peran pemangku kepentingan dapat dikelompokkan menjadi tiga yaitu pemangku kepentingan utama (primer), pemangku kepentingan pendukung (sekunder) dan pemangku kepentingan kunci. Ditambahkan juga bahwa menurut Putri dan Eko B.S (2020) bahwa setiap pemangku kepentingan memiliki pengaruh dan kepentingannya sendiri. Secara skematis kerangka pemikiran analisis pemangku kepentingan dalam kajian ini adalah sebagai berikut.

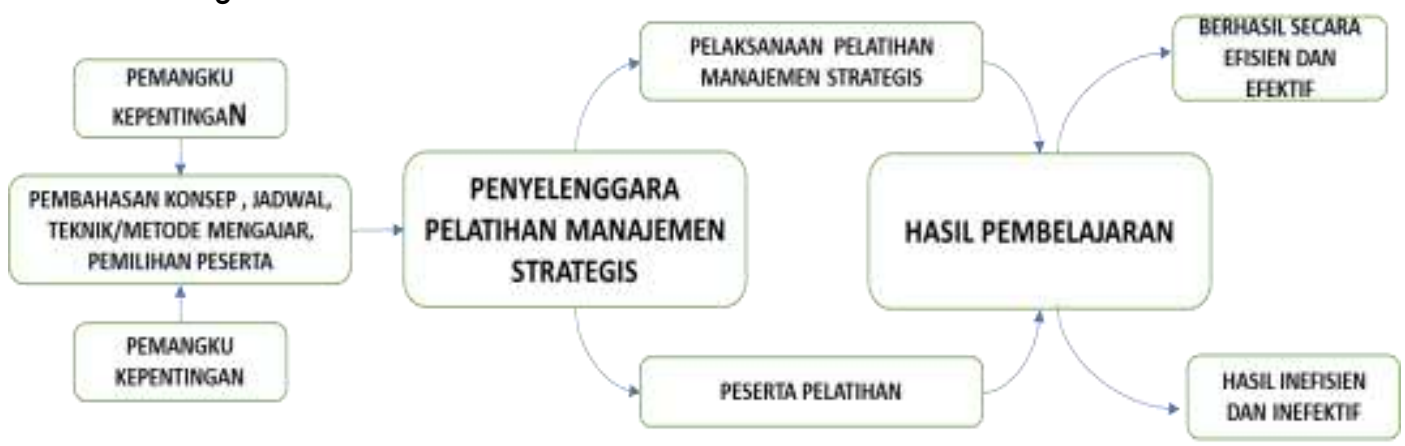

Gambar.1 Kerangka Berfikir Proses Pembelajaran Manajemen Strategis di BPSDM Provinsi DKI Jakarta

Dalam hal pelaksanaan pelatihan manajemen strategis dimulai dengan penyusunan perencanaan pelatihan. Pada awalnya para pemangku kepentingan pelatihan membahas konsep pelatihan manajeman stratetegis. Dari hasil pembahasan outputnya adalah jadwal pembelajaran, tugas dan tanggung jawab pengajar, lembar rencana evaluasi, persiapan penyusunan bahan tayang dan bahan ajar, tugas penyelenggara, penyusunan soal pre test dan post test.

Dalam pelaksanaan maka interaksi antara peserta, penyelenggaraan dan pengajar menjadi lebih aktif. Interaksi yang terencana, terjadwal, dan tersturktur akan menetukan hasil pembelajaran manajemen strategis. Hasil pembelajaran dapat efisien dan efektif sangat tergantung dari kualitas interaksi tersebut. 
Keberhasilan suatu program dalam organisasi tidak hanya ditentukan oleh satu organisasi tetapi sangat tergantung dari berbagai organisasi baik dari instasi pemerintah maupun dari pihak swasta. Untuk itu keberhasilan suatu program diperlukan analisis pemangku kepentingan. yang mana organisasi yang berperan dan mana yang kurang berkenan. Dalam hal ini berdasarkan pengaruh dan kepentingan yang dimiliki oleh setiap stakeholders. Dengan mendasarkan hal ini, stakeholders pembelajaran manajemen strategik dapat dikategorikan menjadi empat jenis, Gardner et al., (1986):

a. Subyek (Subjects). Stakeholders dengan tingkat kepentingan yang tinggi tetapi memiliki pengaruh yang rendah.

b. Pemain Kunci (Key Players). Stakeholders dengan tingkat kepentingan dan pengaruh yang tinggi.

c. Pengikut Lain (Crowd). Stakeholders dengan tingkat kepentingan dan pengaruh yang rendah.

d. Pendukung (Contest setters). Stakeholders dengan tingkat kepentingan yang rendah tetapi memiliki pengaruh yang tinggi

Dari masing masing kategori dapat dimengerti fungsi dan perannnya dalam proses pembelajaran. Oleh karena itu, diperlukan untuk mengetahui perannnya diperlukan kecermatan tersendiri. Dengan diketahuinya peran dan fungsi masing masing pamangku kepentngan dengan tepat maka akan lebih mudah bagi penyusun kebijakan dalam meningkatkan kualitas hasil pembelajaran.

Dengan melihat skema tersebut maka kerjasama dan kolaborasi menjadi suatu keharusan. Sebagaimana disampaikan oleh Nugroho (2019) bahwa untuk melaksanakan peningkatan kompetensi diperlukan kerjasama dan kolaborasi dengan berbagai pihak dalam hal ini adalah stakeholders untuk mengembangkan pembelajran manajemen strategis. Kerjasama dan kolaborasi dalam pelaksanaan kegiatan merupakan langkah tepat guna menyelesaikan seluruh tahapan pengembangan program diklat agar dapat berjalan efektif dan efisien. Tanpa kerjasama dan kolaborasi tentunya mustahil bagi organisasi dapat menjalankan tugas dan fungsinya.

Menurut Fedoral dan Risca (2019) bahwa stakeholder dalam suatu organisasi adalah suatu institusi memiliki peran dan pengaruh yang besar pada keberlangsungan organisasi . dengan demikian maka stakeholder sangat sentral dan menentukan untuk suksesnya suatu organisasi. Mendasarkan hal ini maka sangat beralasan untuk melakukan pemetaan stakeholder dalam mencapai tujuan yang telah ditetapkan dalam organisasi. Hal ini mengingat bahwa dalam praktiknya stakeholder sangat variatif. Stakeholder lainnya atau pendukung terdiri dari komunitas, kelompok aktivis lingkungan atau sosial, dan juga pemerintah maupun pembuat kebijakan lainnya.

Berkaitan dengan analisis pemangku kepentingan menurut Triyanti dan Indah (2019) bahwa kepentingan dan pengaruh stakeholders berdasarkan pemetaan prioritas menunjukkan nilai hak, tanggungjawab, dan manfaat stakeholders menurun sejalan dengan semakin rendahnya tingkat kepentingan dan pengaruh. Jadi dengan demikian maka perlu mendapat perhatian khusus berkaitan dengan peran pemangku kepentingan.

Lokasi kegiatan penelitian dilakukan di BPSDM Provinsi DKI Jakarta Waktu penelitian dilakukan selama 3 bulan yaitu pertengahan Maret sampai dengan Mei 2021. Pelatihan manajemen strategis yang dikaji adalah khusus Angkatan VI dan VII yang pelaksanaanya dilakukan pada bulan Marert dan April 2021.

Stakeholders atau pemangku kepentingan dalam penelitian ini merupakan individu, kelompok, organisasi, atau institusi yang dapat memengaruhi atau dipengaruhi oleh pelaksanaan pelatihan manajemen strategis.

Dalam pengumpulan data, digunakan dengan menggunakan teknik purposive sampling . Metode ini merupakan teknik pengambilan sampel dengan menentukan kriteria-kriteria tertentu (Sugiyono, 2008). Selanjutnya dalam hal ini kriteria yang dipakai dalam penelitian ini adalah SKPD dan UKPD yang terlibat dalam pelatihan menajemen strategis di BPSDM Provinsi DKI Jakarta. Selanjutnya informan dalam hal ini didefiniskan sebagai orang yang menguasai dan memahami data, informasi, ataupun fakta dari suatu obyek yang diteliti. Informan tersebut merupakan representasi pemangku kepentingan penyelenggaraan pembelajaran manajemen strategis. 
Metode pengumpulan data yang dilakukan adalah dengan metode survei menggunakan kuesioner terstruktur, sedangkan pendekatan kualitatif dilakukan dengan observasi mendalam, wawancara dengan narasumber kunci dengan teknik snowball, studi dokumen, dan kemudian membangun analisis dan sintesis atas berbagai data dan informasi yang didapat.

Kajian ini dilakukan secara bertahap. Tahap pertama dalam analisis pemangku kepentingan, adalah Identifikasi Stakeholder. Dalam hal Identifikasi dilakukan untuk mengetahui stakeholders yang terlibat dalam pengembangan pelatihan manajemen strategis. Identifikasi stakeholders dan kepentingannya dilakukan dengan pengamatan dan wawancara langsung dengan metode purposive sampling dan snow-ball sampling. Stakeholders dipilih dengan pertimbangan yang bersangkutan mengikuti pembelajran atau mempengaruhi proses pembelajaran manajeman strategik yang diselenggarkan oleh BPSDM Provinsi DKI Jakarta. Selain itu, peneliti dapat menetapkan stakeholders lainnya yang dipertimbangkan dapat memberikan data lebih lengkap. Stakeholders terdiri dari unsur SKPD dan UKPD di lingkungan Pemerintah Provinsi DKI Jakarta.

Tahap selanjutnya adalah klasifikasi stakeholders. Pada tahap ini yang dilakukan adalah melakukan penafsiran matriks kepentingan dan pengaruh stakeholders terhadap pelatihan manajemen strategis. Dalam penyusunan matriks pengaruh dan kepentingan ini didasarkan pada deskripsi pertanyaan informan yang telah disebaarkan melalui google form. Selanjutnya deskripsi informan dideskripsikan dan dinyatakan dalam ukuran kuantitatif (skor). Langkah selanjutnya adalah dengan mengelompokkan dengan kriteria pengaruh dan kepentingan. Dalam hal pemberian skore digunakan pertanyaan yang tujuannya adalah untuk mengukur tingkat kepentingan dan pengaruh pemangku kepentingan terhadap pembelajaran manajemen strategik.

Berkaitan dengan pengukuran dilakukan pendekatan dengan Teknik ukuran yang digunakan oleh Roslinda et al. (2012). Dalam hal ini ukuran kuantitatif terhadap kepentingan dan pengaruh pemangku kepentingan dilakukan dengan jenjang lima. Selanjutnya dari nilai skor ini dilakukan penjumlahan. Penjumlahan ini dilakukan dengan mengelompokan pada kelompok pengaruh dan kelompok kepentingan masing masing pemangku kepentingan.

Sama dengan pendekatan yang digunakan oleh Roslinda et al, 2012, kemudian dari penjumlahan dilakukan penyusunan koordinat. Dengan menysuun koordinat dengan cara menjumlahkan kelima hasil skoring. Hasil skoring yang dimaksud dalam hal ini adalah hasil skorig dari masing-masing jenis indikator terhadap tingkat kepentingan dan pengaruh masing-masing stakeholders . Dengan dasar ini baru disusun koordinatnya. Posisi koordinat dapat menggambarkan ilustrasi dan peranan yang dimainkan oleh masing-masing stakeholders. Hasil klasifikasi stakeholders berdasar pengaruh dan kepentingannya terbagi ke dalam 4 (empat) golongan yaitu Key Player, Subject, Context Setter dan Crowd.

Selanjutnya dilakkukan analisi hubungan Antar Stakeholders. Hubungan antar stakeholders dipetakan berdasarkan dokumen dan hasil wawancara dengan informan kunci. Pemetaan terhadap hubungan antar stakeholders merupakan gambaran dari hubungan antar stakholders baik yang tertulis di dalam dokumen (tupoksi) maupun yang terlaksana di lapangan dengan metode deskripsi

Selanjutnya analisis yang digunakan dalam penelitian ini mengadopsi model analisis pemangku kepentingan yang dikembangkan (Reed et al., 2009). Focus analisis ini adalah dengan analisis pemangku kepentingan ini untuk menggambarkan kepentingan dan pengaruh pemangku kepentingan dalam memahami sinergi dan konflik antar pemangku kepentingan. Selain itu, dimaksudkan untuk memahami permintaan pemangku kepentingan terhadap pelaksanaan pembelajaran manajemen strategis.

Dalam hal analisis difokuskan pada penafsiran atas data yang telah terkumpul. Secara teknis hal ini dilakukan dengan cara memberikan penafsiran terhadap matriks kepentingan dan pengaruh pemangku kepentingan dalam pelaksanaan pelatihan manajemen strategis yang dilaksanakan di BPSDM Provinsi DKI Jakarta. Peran dan pengaruh pemangku kepentingan dapat dinilai dengan mengukur besar kecilnya intensitas dan kemampuan pemangku kepentingan tersebut mempengaruhi 
atau memaksa pihak lain untuk mengikuti kemauannya. Sumber pengaruh dapat berupa peraturan, dana, opini, informasi, massa, kepemimpinan dan sebagainya .

Selanjutnya untuk mengetahui secara mendalam atas peran pemangku kepentingan, analisis dilanjutkan dengan mengidentifikasi pandangan masing-masing pihak terkait dengan proses pembelajaran manajemen strategis di BPSDM Provinsi DKI Jakarta. Proses yang sama digunakan oleh Ichsan et al. 2017.

Penetapan skoring dilakukan dengan menggunakan daftar pertanyaan untuk mengukur tingkat kepentingan dan pengaruh pemangku kepentingan yang diadopsi dari Roslinda et.al,(2012) yaitu pengukuran data dengan menggunakan lima gradasi yang disajikan pada Tabel 1. Nilai skor dari lima pertanyaan dijumlahkan dan nilainya dipetakan ke dalam bentuk matriks Analisis Stakeholders (Gambar1).

Tabel 1.

Ukuran Kuantitatif terhadap Kepentingan dan Pengaruh Pemangku Kepentingan

\begin{tabular}{llll}
\hline SKOR & Nilai & Kriteria & Keterangan \\
\hline \multicolumn{2}{l}{ Kepentingan Pemangku Kepentingan } & \\
\hline 5 & $21-25$ & Sangat Tinggi & Sangat Mendukung Pelatihan Manajemen Strategis \\
4 & $16-20$ & Tinggi & Mendukung Pelatihan Manajemen Strategis \\
3 & $11-15$ & Cukup Tinggi & Cukup Mendukung Pelatihan Manajemen Strategis \\
2 & $6-10$ & Kurang Tinggi & Kurang Mendukung Pelatihan Manajemen Strategis \\
1 & $0-5$ & Rendah & Tidak Mendukung Pelatihan Manajemen Strategis \\
\hline Pengaruh Pemangku Kepentingan & \\
\hline 5 & $21-25$ & Sangat Tinggi & Sangat Mempengaruhi Pelatihan Manajemen Strategis \\
4 & $16-20$ & Tinggi & Mempengaruhi Pelatihan Manajemen Strategis \\
3 & $11-15$ & Cukup Tinggi & Cukup Mempengaruhi Pelatihan Manajemen Strategis \\
2 & $6-10$ & Kurang Tinggi & Kurang Mempengaruhi Pelatihan Manajemen Strategis \\
1 & $0-5$ & Rendah & Tidak Mempengaruhi Pelatihan Manajemen Strategis \\
\hline
\end{tabular}

Posisi kuadran dapat memberikan penjelasan tentang posisi dan peranan yang dimainkan oleh masing-masing stakeholders terkait dengan pelaksanaan pembelajaran mata pelatihan manajemen strategis, yang dikategorikan berdasarkan (Reed et al., 2009). Hal ini dapat dijelaskan dengan gambar sebagai berikut:

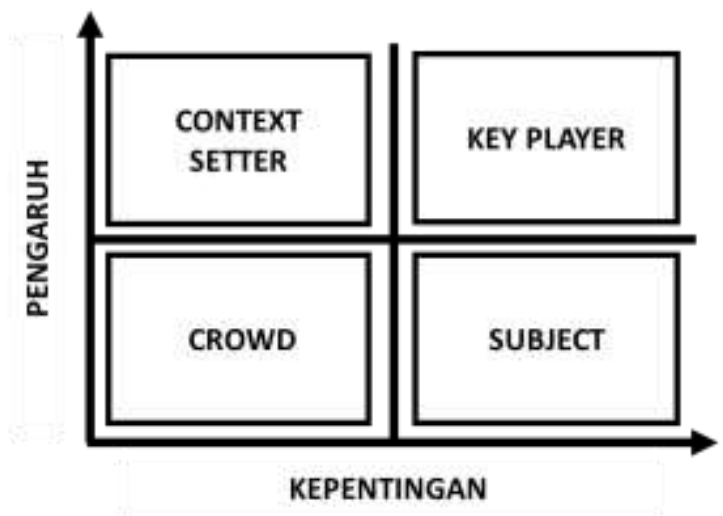

Gambar.2. Matriks Analisis Stakeholders.

Pada gambar 2. Dapat dijelaskan secara deskriptif sebagai berikut.

a. Subjects (Kuadran I) merupakan stakeholders yang memiliki kepentingan yang tinggi tetapi pengaruhnya rendah walaupun mereka mendukung kegiatan, kapasitasnya terhadap dampak mungkin tidak ada. Namun dapat menjadi pengaruh jika membentuk aliansi dengan stakeholders lainnya. 
b. Key Players (Kuadran II) merupakan stakeholders yang aktif karena mereka mempunyai kepentingan dan pengaruh yang tinggi terhadap pengembangan suatu proyek.

c. Crowd (Kuadran III) merupakan stakeholders yang memiliki sedikit kepentingan dan pengaruh terhadap hasil yang diinginkan dan hal ini menjadi pertimbangan untuk mengikutsertakannya dalam pengambilan keputusan.

d. Context Setters (Kuadran IV) memiliki pengaruh yang tinggi tetapi sedikit kepentingan, oleh karena itu, mereka dapat menjadi resiko yang signifikan untuk harus dipantau. Kemudian, analisis dilanjutkan dengan mengidentifikasi pandangan masing-masing pihak terkait dengan proses kolaborasi yang dilakukan dalam pelaksanaaan pembelajaran manajemen strategis.

\section{HASIL DAN PEMBAHASAN}

Dalam penelitian ini dengan mendasarkan pada data dan informasi yang terkumpul ditemukan beberapa hasil dan gambaran berkaitan dengan tingkat pengaruh dan kepentingan masih masing pemangku kepentingan dari setiap actor terhadap proses pembelajaran manajemen strategis yang dilaksanakan di BPSDM Provinsi DKI Jakarta. Temuan dalam penelitian ini dapat dilihat pada uraian berikut ini.

\section{Identifikasi Stakeholders}

Hasil identifikasi stakeholders menunjukkan bahwa stakeholders berasal dari unsur instansi pemerintah pusat dan Pemerintah Provisni DKI Jakarta. Jumlah stakeholders yang terlibat dalam pengembangan pelatihan manajemen strategis di BPSDM Provinsi DKI Jakarta sebanyak 15 (lima belas) instansi. Jumlah dapat diuraikan pada Tabel.2. berikut.

Tabel 2.

Pemangku Kepentingan yang Terlibat Dalam Pengelolaan

\begin{tabular}{cll}
\hline No. & \multicolumn{1}{c}{ Pemangku Kepentingan } & Peran dalam pelatihan Manstra \\
\hline 1 & BPSDM & Pemerintah Provinsi DKI Jakarta \\
2 & Widyaisawara & Pemerintah Provinsi DKI Jakarta \\
3 & BPAD & Pemerintah Provinsi DKI Jakarta \\
4 & RSUD & Pemerintah Provinsi DKI Jakarta \\
5 & Walikota Administrasi & Pemerintah Provinsi DKI Jakarta \\
6 & BPKD & Pemerintah Provinsi DKI Jakarta \\
7 & Kelurahan & Pemerintah Provinsi DKI Jakarta \\
8 & Biro Pemerintahan & Pemerintah Provinsi DKI Jakarta \\
9 & BAPPEDA & Pemerintah Provinsi DKI Jakarta \\
10 & Satpol PP & Pemerintah Provinsi DKI Jakarta \\
11 & BKD & Pemerintah Provinsi DKI Jakarta \\
12 & KORPRI & Pemerintah Provinsi DKI Jakarta \\
13 & Dinas Pemuda dan Olahraga & Pemerintah Provinsi DKI Jakarta \\
14 & Panti Sosial Bina Karya & Pemerintah Provinsi DKI Jakarta \\
15 & Penyelenggara & Pemerintah Provinsi DKI Jakarta \\
\hline
\end{tabular}

Tidak dapat dihindari bahwa stakeholders dari unsur Pemerintah Provinsi DKI Jakarta dalam proses pembelajaran manajemen strategis di BPSDM Provinsi DKI Jakarta memiliki peran yang tidak sama satu sama lain. Bentuk dan peran Stakeholders.tersebut meliputi menyusun pedoman dan modul pembelajaran, menyusun tenaga pengajar, menetukan dan menyusun jumlah 
peserta, mengevaluasi proses pembelajaran, dan sebaganya berkaitan dengan manfaat proses pembelajaran Manajemen Strategis.

\section{Klasifikasi Stakeholder}

Berdasarkan data pengaruh dan kepentingan masing masing aktor yang terlibat dalam pelaksanaan pembelajraan Manajemen Strategis. Posisi dan peranan pemangku kepentingan dapat digambarkan dengan diagaram kuadran. Masing masing aktor-aktor tersebut dapat diklasifikasikan berdasarkan kerangka analisis yang dikembangkan oleh Reed et al. (2009) dengan membagi klasifikasi stakeholders ke dalam empat kuadran yaitu Subjects, Key Players, Crowd dan Context Setters. Secara detail mengenai pembagian aktor yang teribat dalam pengembangan pembelajaran Manajemen Strategis dapat dilihat pada Gambar berikut:

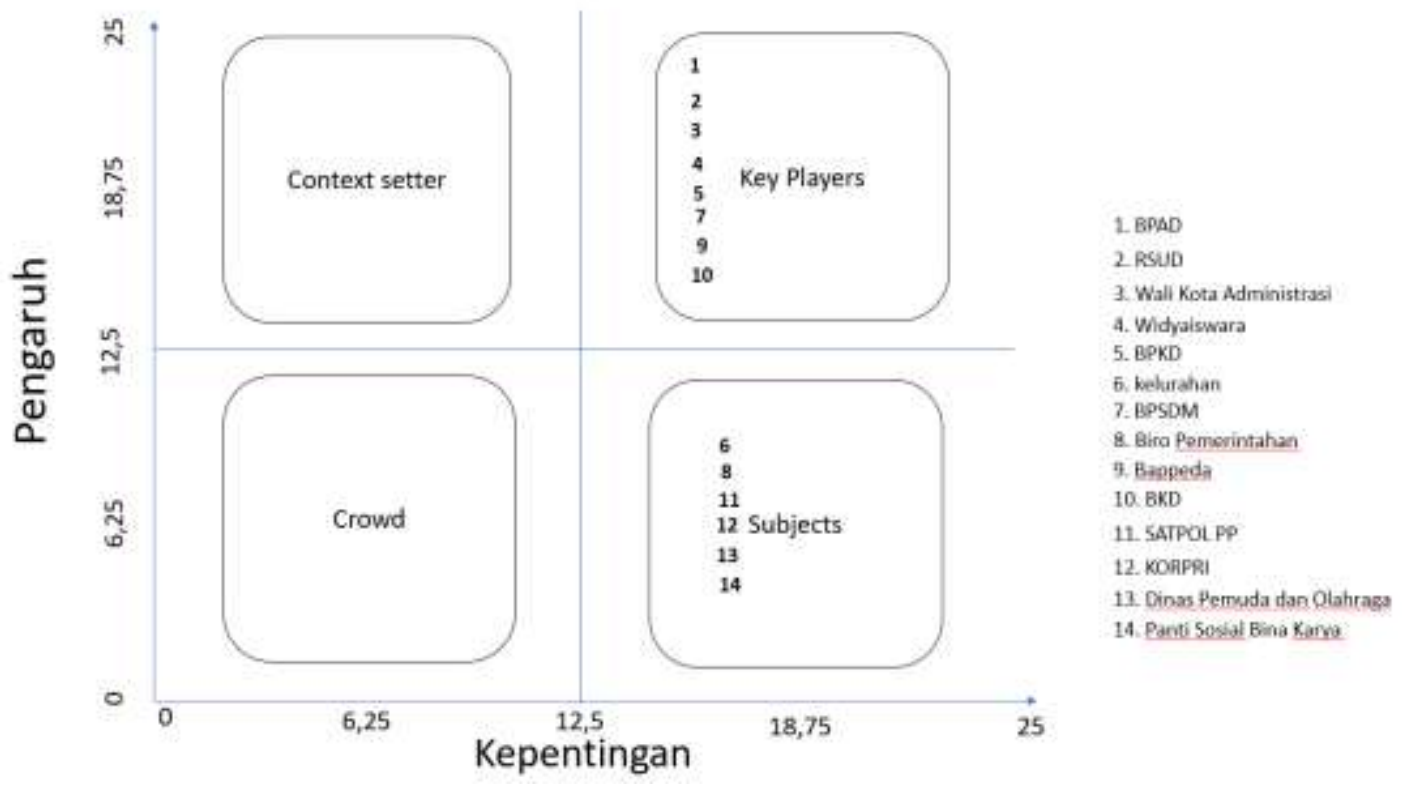

\section{a. Subjects}

Gambar.3. Matirks Kepentingan dan Pengaruh para Pemangku Kepentingan

Stakeholders yang masuk dalam kategori I (Subjects) merupakan pihak dengan kepentingan yang tinggi tetapi memiliki pengaruh yang rendah. Stakeholders yang termasuk dalam klasifikasi Subject terdiri dari Kelurahan, Biro Pemerintahan, Satuan Polisi Pamong Praja, Unit Korpri. Dinas Pemuda dan Olahraga, dan Panti Sosial Bina Karya. Stakeholders tersebut memiliki nilai kepentingan yang tinggi dalam proses pembelajaran tetapi pengaruhnya dalam proses berlangsung pembelajaran Manajemen Strategis rendah.

Jadi jelasnya bahwa terhadap keberhasilan pengembangan pelatihan manajemen strategis di BPSDM Provinsi DKI Jakarta, pemangku kelompok ini tingkat kepentingan yang tinggi namun memiliki pengaruh yang rendah terhadap proses pengembangan pelatihan manajemen strategis di BPSDM Provinsi DKI Jakarta. Dengan demikian dapat dikatakan bahwa stakeholders kelompok ini pengaruhnya rendah tetapi tingkat kepentingannya terhadap porses pembelajaran ini sangat dibutuhkan. Untuk itulah kelompok ini diperlukan keterlibatannya dalam proses pembelajaran dengan maksud agar dapat berpartisipasi dalam proses pengembangan pelatihan manajemen strategis di BPSDM Provinsi DKI Jakarta. Pelibatan stakeholders tersebut dapat dilakukan dengan pemberdayaan dan mengikutsertakannya di setiap tahapan pengembangan.

\section{b. Key Player}

Sesuai dengan matirkx Gambar 3 bahwa kelompok Key Player merupakan kelompok strategis. Kelompok ini merupakan stakeholders yang mempunyai pengaruh dan kepentingan 
yang tinggi. Stakeholders yang berada pada Key Players ini merupakan kelompok yang paling strategis karena memiliki tingkat kepentingan dan tingkat kepengaruhannya yang tinggi terhadap keberhasilan dalam pembelajaran manajemen strategis.

Yang termasuk dalam kelompok key player dalam pembelajaran manajemen strategis adalah Badan Pengelola Aset Daerah, Rumah Sakit Umum Daerah (RSUD), Walikota, Widyaiswara, Badan Pengelola Keuangan Daerah (BPKD), Badan Pengembangan Sumber Daya Manusia (BPSDM) , Badan Perencanaan Pembangunan Daerah (Bappeda) dan Badan Kepegawaian Daerah (BKD). Masing masing instansi ini mempunyai peran yang signifikan dalam menentukan kualitas pembelajaran Manajemen Strategis di BPSDM Provinsi DKI Jakarta.

Sebagai contoh widyaiswara mempunyai peran yang sangat sentral dalam hal ini . argumennya adalah bahwa widyaiswara mempunyai pengalaman yang lengkap. Widyaiswara mempunyai basis praktik yang tinggi dalam hal pengembangan manajemen strategis. Pengalaman dalam mempraktikan teori sudah cukup lengkap dan memadai karena mereka pada umumnya merupakan mantan pejabat structural di SKPD teknis. Jadi widyaiswara memiliki peran yang penting dalam pengembangan pelatihan manajemen strategis di BPSDM Provinsi DKI Jakarta. Widyaiswara mempunyai mempunyai kewenangan dalam Pengembangan Pelatihan Manajemen Strategis.

Selanjutnya BPSDM Provinsi DKI Jakarta mempunyai kepentingan yang tinggi terhadap pengembangan pelatihan manajemen strategis. BPSDM merupakan instansi pemerintah daerah Provinsi DKI Jakarta yang diberikan mandat untuk melaksanakan urusan pemerintah daerah di bidang kepegawaian. BPSDM memiliki tingkat kemampuan yang tinggi dalam memperjuangkan aspirasi dalam pengembangan kepegawaian di Provinsi DKI Jakarta.

Kerjasama antara instansi terkait dengan BPSDM dapat memberikan kontribusi yang besar terhadap pelaksanaan program-program pengembangan pelatihan manajemen strategis di BPSDM Provinsi DKI Jakarta. Dapat dikatakan bahwa tanpa peran aktif instansi terkait maka pembejaran manajemen strategis tidak akan berjalan dengan baik dan hasilanya tidak akan optimal.

Sementara SKPD lain seperti Walikota, BPAD, Kelurahan, Biro Pemerintahan, BPKD, RSUD, BKD, Bappeda juga peran yang strategis dalam pembelajaran manajemen strategis. SKPD ini berkaitan dengan tugas dan fungsinya dalam proses perencanaan pembangunan daerah. Sebagai contoh kelurahan yang harus Menyusun dokumen perencanaan pembangunan dan support dokumen APBD membutuhkan manajemen strategsi dalam kerangka berfikirnya. Dengan penegtahuan kerangka berfikir yang terstruktur maka menjadikan kualitas dokumen tersebut dapat lebih baik dan berkualitas.

Selanjutnya yang termasuk dalam context setter, pengaruhnya tinggi tetapi kepentingannya rendah. Dalam hal ini yang masuk dalam Context Setter tidak teridentifikasi. Demikian juga untuk kelompok Crowd juga tidak terdeteksi. Jadi yang terdeteksi adalah untuk kelompok yang masuk dalam Key Player dan Subject.

\section{Hubungan Stakeholders}

Dalam penelitian ini juga diidentifikasi hubungan antar stakeholder. Dari penelitian ini hubungan tersebut dideskripsikan secara sistematis. Dengan deskripsi ini dapat diperoleh bahwa hubungan antar stakeholders menunjukan alur hubungan antar stakholders baik yang tertulis di dalam dokumen (tupoksi) maupun yang terlaksana di lapangan. Dengan mengetahui hubungan antar stakeholders dapat diperoleh suatu pengertian berupa kesepakatan dan kesepahaman tentang konsep pengembangan pelatihan manajemen strategis di BPSDM Provinsi DKI Jakarta.

Hubungan antar stakeholders dalam pengembangan pelatihan manajemen strategis di BPSDM Provinsi DKI Jakarta teridentifikasi dalam 3 hubungan yaitu hubungan komunikasi, koordinasi dan kerjasama. Komunikasi merupakan bentuk hubungan yang penting dijalin oleh 
para stakeholders. Adanya komunikasi memberikan informasi kepada stakeholders yang terlibat dalam menyampaikan tingkat kepentingan stakeholders yang dapat mendukung program pengembangan pelatihan manajemen strategis di BPSDM Provinsi DKI Jakarta. Koordinasi merupakan hubungan antar stakeholders yang paling banyak ditemukan di lapangan. Bentuk koordinasi yang dilakukan pada program pengembangan pelatihan manajemen stretegis di BPSDM Provinsi DKI Jakarta merupakan bentuk teknis dari pelaksanaan program. Sedangkan bentuk kerjasama merupakan bentuk hubungan yang dilakukan oleh stakeholders yang dilandasi oleh hak dan kewajiban (kontribusi) antar pihak berupa dukungan yang diperlukan dalam program pengembangan pelatihan manajemen strategis di BPSDM Provinsi DKI Jakarta.

\section{a. Komunikasi}

Menurut Hidayat (2012) dalam Rachmayuniawati, 2017. Bahwa komunikasi merupakan usaha untuk membangun sebuah kebersamaan yang dilandasi oleh persamaan persepsi tentang sesuatu sehingga mendorong diantara pelaku komunikasi untuk saling memahami sesuai dengan keinginan atau tujua bersama. Sedangkan menurut Dengan kata lain komunikasi suatu media pertukaran informasi yang dilakukan oleh dua orang atau lebih yang akan saling memberikan pengertian yang mendalam. Dalam komunikasi berarti ada tindakan untuk berbagi informasi, gagasan ataupun pendapat dari setiap partisipan komunikasi yang terlibat di dalamnya guna mencapai kesamaan makna. Dalam komunikasi terkait dengan pengembangan pelatihan manajemen strategis ada tiga unsur penting yang selalu hadir dalam setiap komunikasi yaitu sumber informasi, media dan penerima informasi.

Hubungan komunikasi antara stakeholders terjadi pada hampir seluruh kegiatan pengembangan pelatihan manajemen strategis. Mulai dari inventarisasi dan identifikasi, kegiatan promosi dan publikasi, penysunan desain pembelajara, desain modul, dan rapat rapt persiapan termasuk perekrutan peserta. Hal ini dimaksudkan agar semua pemangku kepentingan memahami dengan baik tentang substansi pokok mata pelatihan pembelajran manajemen strategis di BPSDM Provinsi DKI Jakarta. Hal ini dilakukan guna mengurangi inefektivitas dan inefisiensi.

\section{b. Koordinasi}

Menurut Ndraha (2003: 291), dalam Afendi. S, Masjaya, Burhanudin (2019) bahwa koordinasi merupakan proses penyepakatan bersama secara mengikat berbagai kegiatan atau unsur yang berbeda-beda sedemikian rupa sehingga di sisi yang satu semua kegiatan atau unsur itu terarah pada pencapaian suatu tujuan yang telah ditetapkan dan di sisi lain keberhasilan kegiatan yang satu tidak merusak keberhasilan kegiatan yang lain. Jadi koordinasi merupakan suatu usaha kerja sama antara badan, instansi, atau unit melalui proses penyepakatan bersama secara mengikat berbagai kegiatan atau unsur yang berbedabeda sedemikian rupa untuk mengarahkan pelaksanaan tugas-tugas tertentu agar menghasilkan suatu tindakan yang seragam dan harmonis pada sasaran yang telah ditentukan.

Dengan demikian dapat dikatakan bahwa koordinasi adalah suatu usaha kerja sama antara badan, instansi, unit dalam pelaksanaan tugas-tugas tertentu sedemikian rupa, sehingga terdapat saling mengisi, saling membantu dan saling melengkapi. Hubungan koordinasi antar stakeholders banyak ditemukan di lapangan. Bentuk koordinasi yang dilakukan merupakan bentuk teknis dari pelaksanaan program pengembangan pelatihan manajemen strategis.

BPSDM berkoordinasi dengan pemangku kepentingan dalam penyelenggaraan pelatihan Manajemen Strategis. Koordinasi dilakukan dengan Bappeda, BPKD, Walikota, RSUD, Satpol PP, BPAD, Kelurahan dan Biro Pemerintahan serta BKD. Koordinasi telah dilakukan melalui media zoom meeting mengingat masih mewabahnya Covid 19. Koordinas 
ini dimaksudkan untuk melaksanakan dan mengembangkan pelatihan manajemen strategis yang ada di pemerintahan daerah untuk sinkronisasi materi yang akan disampaikan.

Selain itu, hubungan koordinasi antar stakeholders dilakukan dimaksudkan untuk menyatukan persepsi kegiatan-kegiatan dalam pengembangan pelatihan manajemen strategis. yaitu agar kegiatan bisa berjalan efektif dilakukan koordinasi sehingga dalam pelaksanaannya tidak terjadi tumpang tindih.

Dengan melalui koordinasi yang sistematis dengan menggunakan etika birokrasi yang baik diperoleh hasil yang cukup dapat dipertanggungjawabkan secara administratif. Beberapa kendala yang ditemukan berkaitan dengan koordinasi ini adalah kesediaan waktu dari pejabat yang berwenang sehingga yang hadir diwakilkan kepada bawahannya. Hal ini sering menjadikan yang mewakili tidak bisa mengambil keputusan. Selain itu juga yang mewakili tidak mengikuti dari awal pembahasan. Namun walaupun demikian proses koordinasi dapat berjalan dengan lancar dan pelatihan manajemen dapat dijalankan dengan sukses.

\section{c. Kerjasama}

Secara konsep bahwa agar terwujud efisisensi, efektifitas dan produktivitas pada setiap kegiatan pembangunan, perlu dilakukan kerjasama antar instansi terkait, bahkan perlu sebuah Team Work yang kuat dalam melaksanakan kegiatan pembangunan. Pengalaman menunjukkan bahwa beberapa kegiatan pembangunan masih belum dilakukan secara kerjasama, sehingga akibatnya adalah bahwa hasil pembangunan menjadi kurang maksimal, kurang efektif kurang eifisen dan kurang tepat sasaran.

Menurut Sarwono (2011:139) dalam Lakoy 2015 mengatakan bahwa kerjasama merupakan bentuk kelompok yang terdiri dari lebih dari seseorang yang melakukan tugas dengan sejumlah peraturan dan prosedur. Untuk itulah bahwa dalam pelaksanaan kerjasama harus tercapai keuntungan bersama, Pelaksanaan kerjasama hanya dapat tercapai apabila diperoleh manfaat bersama bagi semua pihak yang terlibat di dalamnya(win-win). Apabila satu pihak dirugikan dalam proses kerjasama, maka kerjasama tidak lagi terpenuhi. Dalam upaya mencapai keuntungan atau manfaat bersama dari kerjasama, perlu komunikasi yang baik antara semua pihak dan pemahaman sama terhadap tujuan bersama. Dengan kata lain bahwa kerjasama (cooperation) adalah usaha bersama antara individu atau kelompok untuk mencapai satu atau beberapa tujuan bersama proses terjadinya cooperation apabila di antara individu atau kelompok tertentu menyadari adanya kepentingan dan ancaman yang sama.

Kerjasama antar stakeholders terkait dengan pengembangan pelatihan manajemen strategis di BPSDM Provinsi DKI Jakarta sebagian besar merupakan hubungan kerjasama atas dasar tugas dan fungsi masing masing SKPD/UKPD dan aturan kelembagaan. Selain itu dilandaskan juga kesamaan visi dan misi. Dengan demikian terjadi konvergensi tujuan termasuk dalam pembelajaran manajemen strategis di BPSDM Provinsi DKI Jakarta. Tanpa kerjasama professional dan proporsional maka pembelajran manajemen strategis tidak dapat berjalan dengan baik dan hasilnya tentu juga kurang optimal terutama dalam penerapan dalam praktik penyusunan dokumen perencanaan pembangunan daerah pada tiap tiap SKPD/UKPD.

\section{SIMPULAN DAN SARAN}

Pengembangan Pelatihan Manajemen Strategis di BPSDM Provinsi DKI Jakarta perlu mendapatkan perhatian dari berbagai pemangku kepentingan yang mempunyai kepentingan dan pengaruh dengan pengembangan Pelatihan Manajemen Strategis di BPSDM Provinsi DKI Jakarta. Berdasarkan hasil identifikasi pemangku kepentingan diketahui bahwa terdapat 15 (lima belas) 
pemangku kepentingan yang terlibat dalam pengembangan pelatihan manajemen strategis di BPSDM Provinsi DKI Jakarta yang terdiri dari pemangku kepentingan kunci yaitu BPSDM, BKD, BAPPEDA, BPKD dan BPAD Provinsi DKI Jakarta.

Pelatihan bagi PNS sangat dibutuhkan untuk meningkatkan kompetensi dalam menajalankan tugas dan fungsinya. Dalam pengembangan kompetensi bagi PNS dapat dilakukan melalui jalur pendidikan dan/atau pelatihan. Oleh karena itu maka pemeblajaran manajemen strategis menjadi sangat penting dan strategis.

Ruang kolaborasi yang tersedia masih dapat dimanfaatkan lebih baik lagi melalui proses komunikasi, koordinasi, dan Kerjasama yang lebih intensif dengan para pihak yang terlibat. Hal tersebut diharpkan dapat meningkatkan kesamaan persepsi dari masing-masing pihak dalam memaknai proses kolaborasi yang dibangun.

Untuk terwujudnya output pembelajaran yang optimal maka diperlukan komunikasi, koordinasi dan kerjasama antar pemangku kepentingan. Kerjasama ini diarahkan pada kerangka kolaborasi sesuai dengan tugas dan fungsi masing-masing SKPD/UKPD. Hal yang perlu menjadi perhatian serius lagi adalah bahwa dalam hal kolaborasi diperlukan semangat professional dan proporsional antar instansi. Selain itu dalam berkolaborasi antar instasni harus dilakukan secara efektif dan efeisien serta harus didukung komunikasi, koordinasi , dan kerjasama yang seimbang dan saling menghormati.

\section{DAFTAR PUSTAKA}

Afendi. S, Masjaya, Burhanudin , 2019. Koordinasi Pemerintahan Dalam Pengendalian Daerah Aliran Sungai (Das) Karang Mumus Di Kota Samarinda. eJournal IImu Pemerintahan , 2019, 7 (2): 545-558 ISSN 2477-2458 (online), ISSN 2477-2631 (cetak), ejournal.ipfisip-unmul.ac.id .

Bryson, J. M. (2004). What to do when stakeholders matter: stakeholder identification and analysis techniques. Public Management Review, 6(1), 21-53. doi:10.1080/14719030410001675722.

Fedora1, S.D. dan Risca F.H. (2019). Analisis Pemangku Kepentingan (Stakeholder) Pada Unit Hubungan Masyarakat (Humas) Dan Kesekretariatan PT. Semen Padang. Jurnal Administrasi Bisnis Terapan Volume 2 Nomor 1, Juli - Desember 2019 P-ISSN : 2622-1772 E- ISSN 26215993.

Gardner, J. R., Rachlin, R. and Sweeny, H.W.A. (1986). Handbook of Strategic Planning.http://www.12manage.com/methods_stakeholder_mapping.html

Hidayah, N., Hutagalung, S. S., \& Hermawan, D. (2019). Analisis peran stakeholder dalam pengembangan wisata talang air peninggalan kolonial Belanda di Kelurahan Pajaresuk Kabupaten Pringsewu. Jurnal IImu Administrasi Publik, 7(1), 55-71. doi:10.31289/publika.v7i1.2179.

Ichsan1 Andi Chari, R Soekmadi, S.Adiwibowo dan C. Kusmana, , 2017. Peran Pemangku Kepentingan Dalam Pelaksanaan Model Desa Konservasi Di Taman Nasional Gunung Rinjani (Role of Stakeholders in the Implementation of Conservation Village Model in Mount Rinjani National Park). Jurnal Analisis Kebijakan Kehutanan Vol. 14 No.1, Mei 2017 : 47- 59 p-ISSN 0216-0897 e-ISSN 2502-6267

Lakoy A.C. (2015). Pengaruh Komunikasi, Kerjasama Kelompok, Dan Kreativitas Terhadap Kinerja Karyawan Pada Hotel Aryaduta Manado. Jurnal EMBA 981 Vol.3 No.3 Sept. 2015, Hal.981-991 ISSN 2303-11.

Nugroho, Yudistira Adi (2019) . Analisis Stakeholders Dalam Pengembangan Program Diklat Di Balai Diklat Aparatur Kementerian Kelautan Dan Perikanan. Jurnak Manajemen \& Bisnis Kreatif. Vol. 5 No 1 ISSN: 2528-0597 E-ISSN: 2580-5428.

Putri, Putu Ayu dan Eko Budi Santoso (2020). Analisis Pemangku Kepentingan dalam Pengembangan Kawasan Cagar Budaya sebagai Destinasi Wisata Kota Pontianak Jurnal Wilayah Dan 
Lingkungan P-ISSN: 2338-1604 dan E-ISSN: 2407-8751 Volume 8 Nomor 3, Desember 2020, p. $202-213$

Ray, Raymundus I Wayan . 2018. Perencanaan Manajemen Strategis Dan Kepuasan Kerja Terhadap Kinerja Pegawai (Studi Kasus Pada KRL Commuter Line Bogor-Jakarta). Business Management Journal Vol.14 (No. 2 ) : 75 - 153. Th. 2018 ISSN: 1907-0896 E-ISSN: 2598-6775.

Rachmayuniawati, Y. (2017) Pengaruh Komunikasi Internal dan Koordinasi Terhadap Efektivitas Kerja pada Pegawai Rumah Sakit Prasetya Bunda Tasikmalaya. JIMFE (Jurnal IImiah Manajemen Fakultas Ekonomi) Vol. 4 No. 1, Juni 2018, Hal. 67-80 P-ISSN: 2502-1400, E-ISSN: 2502-5678.

Reed, S.M., A. Graves, N. Dandy, H. Posthumus, K. Hu- back, J. Morris, C. Prell, C.H. Quin, L.C. Stringer, 2009. Who's in and why? w typology of stakeholder analysis methods for natural resource management. Journal of Envi- ronmental Management. 90, pp. 1933-1949.

Roslinda. E., D. Darusman, D. Suharjito, D.R. Nurrochmat, 2012. Analisis pemangku kepentingan dalam pengelolaan taman nasional danau sentarum kabupaten Kapuas Hulu, Kalimantan Barat. Jurnal Manajemen Hutan Tropika. 18(2), pp. 78-85.

Sugiyono. (2008). Metode Penelitian Bisnis. Alfabeta: Bandung

Triyanti, R dan Indah Susilowati, (2019). Analisis Pemangku Kepentingan Dalam Pengelolaan Kawasan Pesisir Berkelanjutan Di Kabupaten Gunungkidul. Jurnal. Kebijakan Sosek KP Vol. 9 No. 1 Juni 2019: 23-35.

Undang-Undang Nomor 23 Tahun 2014 tentang Pemerintahan Daerah

Undang-Undang Nomor 5 Tahun 2014 Aparatur Sipil Negara

https://covid19.go.id Tujuh Kiat Sukses Bersekolah dengan Pembelajaran Daring 